Abstracta Iranica

Revue bibliographique pour le domaine irano-aryen

Volume 34-35-36 | 2017

Comptes rendus des publications de 2011-2013

\title{
Denise Aigle. Essai sur les autorités religieuses de l'islam médiéval oriental
}

\section{Pierre Lory}

\section{(2) OpenEdition \\ 1 Journals}

\section{Édition électronique}

URL : http://journals.openedition.org/abstractairanica/41932

DOI : 10.4000/abstractairanica.41932

ISSN : 1961-960X

Éditeur :

CNRS (UMR 7528 Mondes iraniens et indiens), Éditions de l'IFRI

\section{Référence électronique}

Pierre Lory, «Denise Aigle. Essai sur les autorités religieuses de l'islam médiéval oriental », Abstracta Iranica [En ligne], Volume 34-35-36 | 2017, document 4, mis en ligne le 30 décembre 2016, consulté le 03 octobre 2020. URL : http://journals.openedition.org/abstractairanica/41932 ; DOI : https://doi.org/ 10.4000/abstractairanica.41932

Ce document a été généré automatiquement le 3 octobre 2020.

Tous droits réservés 


\title{
Denise Aigle. Essai sur les autorités religieuses de l'islam médiéval oriental
}

\author{
Pierre Lory
}

\section{RÉFÉRENCE}

Denise Aigle. «Essai sur les autorités religieuses de l'islam médiéval oriental », in : D. Aigle, dir., Les autorités religieuses entre charisme et hiérarchie. Approches comparatives. Turnhout, Brepols, 2011, p. 17-40

1 Ce chapitre de présentation offre une synthèse méthodologique très dense sur la façon d'aborder comme historien le rôle des hommes exerçant une autorité religieuse en islam médiéval. Y sont abordés : l'extension même du concept de 'religion' et ses rapports avec les autres faits sociaux, les questions des approches macro- et microhistoriques; l'approche des différents documents historiographiques en islam. Les données distinguant le savant ('âlim) et le 'saint homme' (walī) sont soulignés, comme l'hétérogénéité sociale de ces deux figures ; ainsi que le rôle actif et particulier du modèle muhammadien. Les mouvements socialement marginaux sont également évoqués, avec leur portée religieuse éventuelle.

\section{AUTEURS \\ PIERRE LORY \\ EPHE, Paris}

